УДК 338.3

DOI: https://doi.org/10.37320/2415-3583/10.12

\section{Старко I.C. \\ кандидат економічних наук, \\ Львівський техніко-економічний коледж \\ Національного університету «Львівська політехніка»}

Канцір I.A.

кандидат економічних наук,

Національний університет «Львівська політехніка» ORCID: https://orcid.org/0000-0002-1259-0381

Шевчук М.П.

Інститут інноваційної освіти Київького національного університету архітектури та будівництва

\title{
СУЧАСНА ПАРАДИГМА УПРАВЛІННЯ ПРИБУТКОВІСТЮ
}

\begin{abstract}
Метою функиіонування будь-якого суб 'єкта господарської діяльності виступає максимізація прибутку у довгостроковому періоді. Ефективне управління формуванням та розподілом прибутку слугує платформою розвитку підприємства, підвищення його рейтингових показників, залучення інвестицій, розширення масштабів діяльності. Оиіночним показником ефективності управління прочесом отримання й розподілу прибутку вважається прибутковість. Одним із найефективніших методів оцінки впливу витрат, иіни, обсягу реалізованої продукиї на фінансовий результат діяльності підприємства виступає аналіз співвідношень - CVP-аналіз, який за допомогою системи показників оптимізує співвідношення між постійними та змінними витратами, регулює механізм иіноутворення, мінімізує рівень підприємницького ризику, провадить моніторинг фінансових результатів (факт-прогноз), забезпечує запас фінансової стійкості та обтрунтує механізм оптимізацї фінансово-господарської діяльності підприємства.
\end{abstract}

Ключові слова: прибуток, фінансовий результат, прибутковість, чинники впливу, конкурентоспроможність, аналіз.

Постановка проблеми. Діяльність будь-якого підприємства зорієнтована на отримання результатів діяльності, які формуються внаслідок реалізації економічних, технічних, стратегічних, соціальних, організаційних завдань його функціонування. Поширення набуває твердження щодо збиткової діяльності вітчизняних підприємств різних видів діяльності та форм господарювання. Зазначена позиція підлягає переоцінці, адже, за даними Державної служби статистики України, переважна більшість галузей національної економіки у 2018 р. була прибутковою (за винятком транспорту, складського господарства, поштової та кур'єрської діяльності; операцій із нерухомим майном; діяльності у сфері адміністративного та допоміжного обслуговування; мистецтва, спорту, розваг та відпочинку). Питання оцінювання результатів та проведення ефективного управління ними потребують перманентного аналізу, модернізації методики.

Аналіз останніх досліджень і публікацій. Дослідженню особливостей формування прибутковості діяльності підприємств, управління нею та шляхів іiі підвищення присвячено праці В.В. Апопія, І.Ю. Єпіфанової, Т.В. Осипової, А.А. Мазаракі, А.В. Савицького та інших учених. Водночас питання комплексного підходу до оптимізації механізмів управління прибутковістю $\epsilon$ нагальним і з урахуванням викликів часу потребує подальших наукових досліджень.
Мета статті полягає у визначенні сутності прибутку та механізмів ефективного управління прибутковістю суб'єктів господарювання в умовах трансформаційних перетворень.

Виклад основного матеріалу. Місією функціонування суб'єкта господарювання є отримання позитивного результату фінансово-господарської діяльності та максимізація прибутку. Ефективне управління формуванням та розподілом прибутку слугує платформою розвитку підприємства, підвищення його рейтингових показників, залучення інвестицій, розширення масштабів діяльності. Зазначена місія може бути реалізованою лише за умови ефективного менеджменту процесів прибутковості.

Прибуток - це економічний показник, який відображає позитивний фінансовий результат діяльності підприємства за певний часовий період, характеризує ефективність виробництва i, зрештою, свідчить про рівень і якість виробленої продукції, стан продуктивності праці, рівень собівартості.

Водночас прибуток впливає на зміцнення фінансового стану підприємства, інтенсифікацію виробництва за будь-якої форми власності. Він $\epsilon$ не лише джерелом забезпечення внутрішньогосподарських потреб підприємств, а й джерелом формування бюджетних ресурсів держави. Загальний прибуток підприємства являє собою кінцевий результат діяльності підприємства [1]. 
Соціально-економічна сутність прибутку найповніше виявляється в його функціях, до яких відносять:

- облікову й індикативну (прибуток - це критерій ефективності господарської діяльності фірми);

- розподільчу (прибуток - це основне фінансове джерело функціонування економічних одиниць різних рівнів управління);

- стимулюючу (прибуток - це генератор економічного, інвестиційно-інноваційного розвитку).

Домінуючими чинниками визначення абсолютного розміру показника прибутку зазвичай уважаються ендогенні чинники, зокрема: обсяг реалізації продукції, товарів, робіт та послуг; маркетингова політика; кадровий потенціал; корпоративна культура; соціальний характер діяльності; матеріально-технічне забезпечення; інноваційний характер діяльності (рис. 1).

Чинники впливу на прибуток $є$ мотиватором управлінських дій, адже зміна одного $з$ них безпосередньо або опосередковано зумовлює прийняття рішень щодо коригування вибраної підприємством політики ведення бізнесу.

Особливо актуальним для проведення оцінки ефективності діяльності підприємства вважається моніторинг його прибутковості. Т.В. Осипова [2] вважає, що основою прибутковості є сам прибуток, який у цілому й визначає результат фінансово-господарської діяльності підприємств.
Існують два основні підходи до визначення рівня виробництва, за якого фірма буде отримувати максимальний прибуток або мінімальний збиток:

1) порівняння валового доходу та валових витрат;

2) порівняння граничного доходу та граничних витрат.

Розподіл і використання прибутку є найважливішим господарським процесом, що забезпечує покриття потреб підприємців і формування доходів держави. Механізм розподілу прибутку повинен бути побудований так, щоб усіляко сприяти підвищенню ефективності виробництва, стимулювати розвиток нових форм господарювання. Прибуток підприємства, отриманий у результаті його господарської діяльності, розподіляється між державою та підприємством [3].

Стратегічна орієнтація системи управління прибутком визначається в розрізі перспективних орієнтирів діяльності підприємства на основі аналізу, оцінки та прогнозування стану ринкового середовища, визначення рівня одержуваного прибутку і можливостей управління ним із метою його оптимізації. Розроблення альтернативних варіантів вирішення тактичних i стратегічних завдань, а також можливість моделювання альтернативних варіантів у концепції інтегрованості управління прибутком із загальною системою

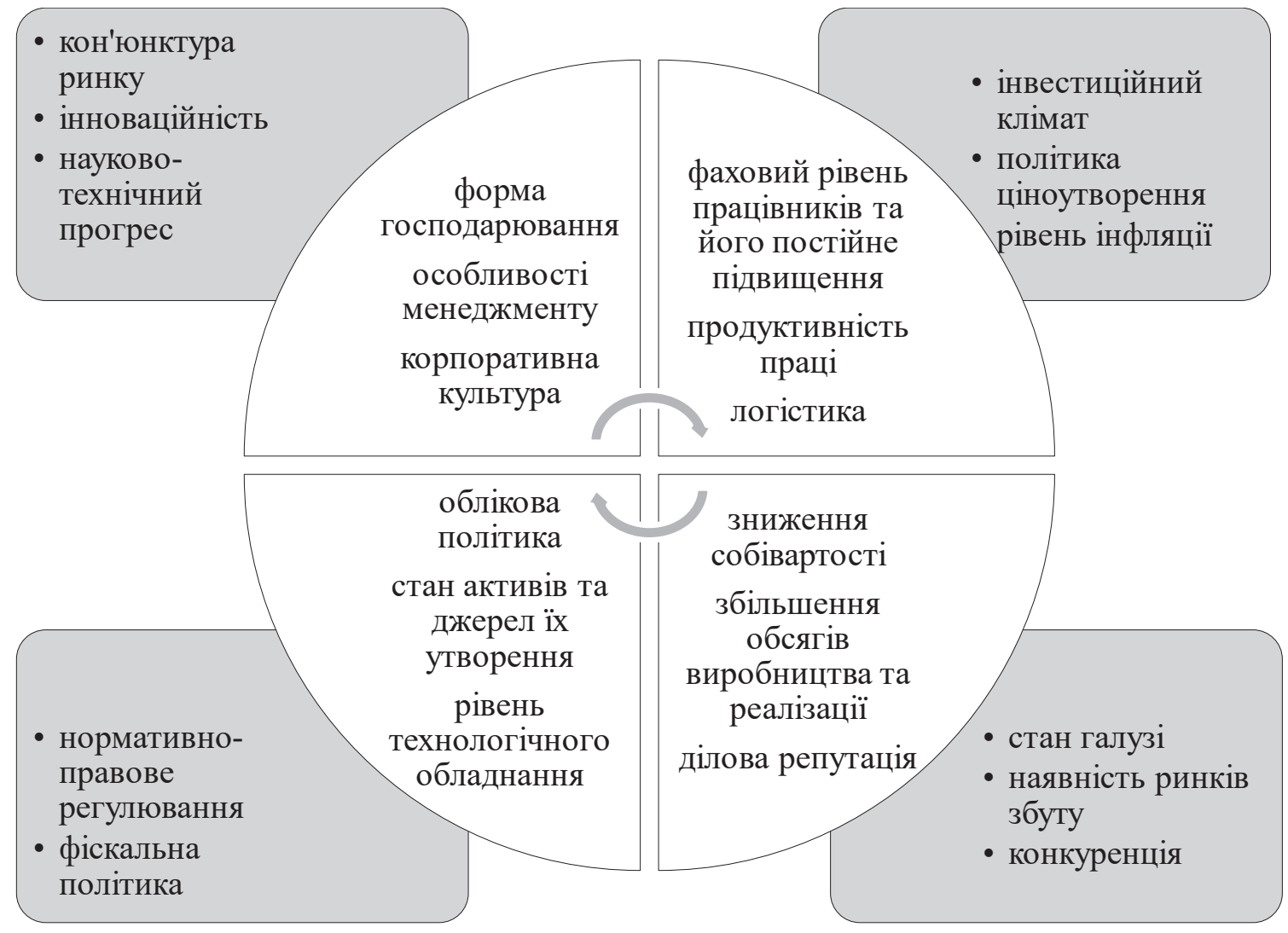

Рис. 1. Чинники впливу на прибуток 
управління підприємством є одним 3 основних елементів управління прибутком [4, с. 28-36].

Прибутковість - це відносний показник, який характеризує ефективність діяльності суб'єкта господарювання у контексті спроможності отримувати прибуток у процесі ефективного розподілу й відтворення виробничих ресурсів.

Прибутковість являє собою стійке економічне явище, що проявляється як підтверджена здатність підприємства генерувати позитивний фінансовий результат від здійснення як основної, так і всієї господарської діяльності, що полягає у перевищенні доходу над здійсненими витратами в розмірі, достатньому для ефективного подальшого функціонування [5].

Процес управління прибутковістю підприємства реалізується за допомогою специфічного фінансового механізму іiі управління 3 метою визначення стійкості та ефективності функціонування суб'єкта господарювання (рис. 2).

Для збільшення прибутковості доцільно було б використовувати три альтернативи, які $\epsilon$ дуже актуальними:

1) Збільшення цін за збереженого значення витрат. Заробіток може бути збільшений кількома шляхами: підняттям цін на ваш продукт; підняттям рівня продажів; збільшенням різниці між ціною і собівартістю товару.

2) Зниження витрат або собівартості за збереженого значення заробітку. Другою альтернативою є зниження суми загальних витрат. Це може бути досягнуто зменшенням собівартості товару, уведенням в експлуатацію продукції високих технологій, тобто конвеєрів, які ефективно вирішують цю проблему. Іншим важливим інструментом у зниженні загальних витрат є впровадження нових методів управління, таких як спільна діяльність.

3) Одночасне збільшення цін та зменшення собівартості. Це може бути досягнуто шляхом масового виробництва. Принцип економіки, зумовлений зростанням масштабу виробництва, може призвести до бажаної мети [7].

Аналіз прибутковості дає змогу ефективно коригувати політику управління, вибирати ефективну інвестиційну стратегію та максимізувати доходи суб'єкта господарювання.

На нашу думку, одним із найефективніших методів оцінки впливу витрат, ціни, обсягу реалізованої продукції на фінансовий результат діяльності підприємства виступає аналіз співвідношення «витрати - обсяг - прибуток» (Cost Volume - Profit - CVP-аналіз).

CVP-аналіз за допомогою системи показників (точки беззбитковості (порогу рентабельності), коефіцієнта маржинального прибутку, середньозваженого коефіцієнта маржинального прибутку, маржі безпеки та операційного важеля) дає змогу:

- оптимізувати пропорції між змінними i постійними витратами, між ціною та обсягами реалізації продукції;

- мінімізувати підприємницький ризик;

- оцінювати та прогнозувати фінансові результати;

- виявляти резерви та забезпечувати достатній запас фінансової стійкості;

- обгрунтовувати рекомендації щодо оптимізації фінансово-господарської діяльності підприємства.

Прибутковість - це не випадковий результат діяльності декларативного характеру, а ефект поступової реалізації стратегічного плану діяльності.

Нормативно-правове регулювання процесу

формування та розподілу прибутку

Ринковий механізм регулювання процесу

формування і використання прибутку

Внутрішньофірмовий механізм регулювання процесу

формування і використання прибутку

Система специфічних методів та прийомів процесу

формування, управління та розподілу прибутку

Рис. 2. Механізм управління формуванням прибутковості підприсмства

Джерело: сформовано на основі [6] 


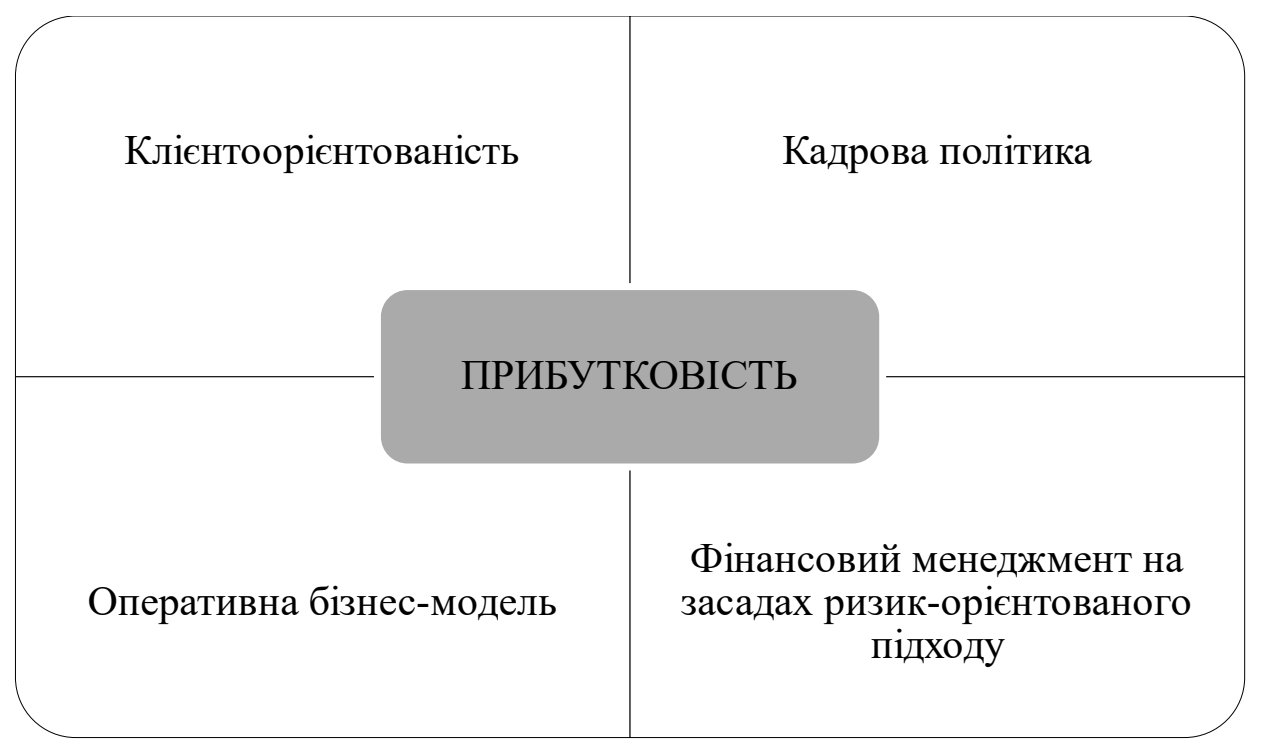

Рис. 3. Платформи управління підвищенням прибутковості

Прибутковість уважається лакмусом ефективності управління підприємством, адже лише отримання прибутку звітного періоду не є віддзеркаленням результативної діяльності (рис. 3). Позитивний фінансовий результат функціонування суб'єкта господарювання повинен, з одного боку, компенсувати ризики діяльності, а з іншого - спонукати до реалізації стратегічних цілей у довгостроковій перспективі.

На нашу думку, оптимальними заходами підвищення прибутковості виступають: пошук альтернатив зменшення витрат, диверсифікація пропозиції; використання сучасних аналітичних інструментів; перманентне підвищення кваліфікації працівників; оптимізація виробничих процесів шляхом імплементації сучасних IT-систем управління виробничим потенціалом; формування сучасної екосистеми підприємства; підвищення іміджу; постійний маркетинговий аналіз ринку; клієнтоорієнтованість; формування клієнтського порталу; проведення фінансового аналізу або аудиту 3 метою зниження властивого ризику.

Висновки. Для максимізації прибутку підприємству необхідно сформувати власну ефективну модель управління прибутковістю на основі CVP-аналізу. Домінуючими чинниками забезпечення ефективного стратегічного розвитку підприємства в контексті забезпечення його прибутковості виступають: достатність власного капіталу, функціонування системи ефективного менеджменту, наявність кваліфікованого персоналу, забезпеченість новітніми технологіями, використання інноваційних розробок із метою виробництва високоякісної конкурентоспроможної продукції, функціонування підрозділу внутрішнього аудиту.

\section{Список використаних джерел:}

1. Спіфанова І.Ю., Гуменюк В.С. Прибутковість підприємства: сучасні підходи до визначення сутності. Економіка та суспільство. 2016. Вип. 3. С. 189-192. URL : http://еconomyandsociety.in.uа (дата звернення: 25.12.2019).

2. Осипова Т.В. Теоретичні аспекти трактування прибутковості в сучасних умовах господарювання. Управління розвитком. 2012. № 1. С. 82-84.

3. Блонська В.І., Паньків І.В. Прибуток - особливості його формування та використання в ефективному управлінні підприємством. Науковий вісник НЛТУ України. 2014. Вип. 6. С. 129-134.

4. Звірько Г.П. Методичні підходи до аналізу прибутковості господарської діяльності господарського суб'єкта господарювання. Вісник Національного технічного університету «Харківський політехнічний інститут». 2011. № 7. С. $28-36$.

5. Мелень О.В., Холондач Ю.Ю. Актуальні питання прибутковості підприємства та шляхи їі збільшення. Вісник Національного технічного університету «ХПІ». Тематичний випуск «Технічний прогрес $і$ ефективність виробництва». 2015. № 25(1134). С. 123-126.

6. Головніна О.Г. Основи соціальної економіки : підручник ; 2-е вид., перероб. та доп. Київ : Центр учбової літератури, 2013. С. 153-157.

7. Романова Т.В., Даровський Є.О. Чинники, що впливають на збільшення прибутку підприємств України в сучасних умовах. Ефективна економіка. 2015. № 4. URL : http://www.economy.nayka.com.ua/?op=1\&z=3976 (дата звернення: 23.12.2019). 


\section{References:}

1. Yepifanova I., Humenyuk V. (2016). Prybutkovist' pidpryyemstva: suchasni pidkhody do vyznachennya sutnosti [Profitability of the enterprise: modern approaches to definition of essence]. Economy and society, vol. 3, pp. 189-192. (in Ukrainian) URL : http://economyandsociety.in.ua (accessed 25 December 2019).

2. Osypova T. (2012). Teoretychni aspekty traktuvannya prybutkovosti v suchasnykh umovakh hospodaryuvannya [Theoretical aspects of the interpretation of profitability in modern economic conditions]. Development Management, vol. 1, pp. 82-84. (in Ukrainian)

3. Blons'ka V., Pan'kiv I. (2014). Prybutok - osoblyvosti yoho formuvannya ta vykorystannya v efektyvnomu upravlinni pidpryyemstvom [Profit - features of its formation and use in effective enterprise management]. Scientific Bulletin of NLTU of Ukraine, vol. 6, pp. 129-134. (in Ukrainian)

4. Zvir'ko H. (2011). Metodychni pidkhody shchodo analizu prybutkovosti hospodars'koyi diyal'nosti hospodars'koho sub"yekta hospodaryuvannya [Methodical approaches to the analysis of profitability of economic activity of an economic entity]. Bulletin of the National Technical University "Kharkiv Polytechnic Institute", vol. 7, pp. 28-36. (in Ukrainian)

5. Melen' O., Kholondach Y. (2015). Aktual'ni pytannya prybutkovosti pidpryyemstva ta shlyakhy yiyi zbil'shennya [Topical issues of enterprise profitability and ways to increase it]. Bulletin of the National Tech. KPI University: a collection of scientific works, vol. 25(1134), pp. 123-126. (in Ukrainian)

6. Holovnina O. (2013). Osnovy sotsial'noyi ekonomiky : pidruchnyk. 2-he vydannya, pereroblene ta dopovnene [Fundamentals of social economy]. Kyiv: Center for Educational Literature. (in Ukrainian)

7. Romanova T., Darovs'kyy Y. (2015). Chynnyky, shcho vplyvayut' na zbil'shennya prybutku pidpryyemstv Ukrayiny $\mathrm{v}$ suchasnykh umovakh [Factors influencing the increase of profit of Ukrainian enterprises in modern conditions]. An efficient economy. (in Ukrainian) URL : http://economyandsociety.in.ua (accessed 23 December 2019).

\section{Starko Iryna \\ Lviv Technical and Economic College of the Lviv Polytechnic National University}

Kantsir Iryna

Lviv Polytechnic National University

Shevchuk Maria

Institute of Innovative Education

Kyiv National University of Architecture and Construction

\section{THE MODERN PARADIGM OF THE PROFIT MANAGEMENT}

The article is devoted to determining the essence of profit and finding ways to form an effective mechanism for managing profitability. The purpose of any business entity is to maximize profits over the long term. Effective management of benefits at the enterprise serves as a platform for its maximization, increasing the level of competitiveness of the company. The purpose of the study is to determine the nature of profits and mechanisms of effective management of the profitability of economic entities in the context of transformational transformations. In the process of research used general scientific and unique methods of scientific cognition: abstract-logical (in disclosing the essence of profit, in generalizing and formulating conclusions); synthesis and system analysis (to substantiate the essential characteristics of advantage and profitability as a method of managing it); systematic analysis and theoretical generalization (to formulate the feasibility of introducing CVP analysis into profitability management techniques); logical generalization (to substantiate approaches and suggestions for improving the efficiency of enterprise profitability management). According to the results of the study, the factors of influence on profit has systematized. The ways and directions of management of the process of receiving and distribution of benefit have outlined, the mechanism of profitability management has represented. Profitability has determined to be a relative indicator that characterizes an entity's performance in the context of its ability to generate revenue through the efficient allocation and reproduction of productive resources. The dominant factors for ensuring the active strategic development of the enterprise in the context of ensuring its profitability are sufficiency of own capital, functioning of the system of active management, availability of qualified personnel, availability of the latest technologies, use of innovative developments to produce high-quality, competitive products. One of the most effective methods of managing a company's profitability is the introduction of CVP-analysis, which through the system of indicators optimizes the relationship between fixed and variable costs, controls the pricing mechanism, minimizes the level of entrepreneurial risk, monitors financial results (fact-forecast), justifies the device of optimization of financial and economic activity of the enterprise.

Key words: profit, financial result, profitability, impact factors, competitiveness, analysis.

JEL classification: D21, L20. 